University of Nebraska - Lincoln

DigitalCommons@University of Nebraska - Lincoln

2004

\title{
The New Negro Arts and Letters Movement Among Black University Students in the Midwest, 1914-1940
}

Richard M. Breaux

University of Nebraska-Omaha

Follow this and additional works at: https://digitalcommons.unl.edu/greatplainsquarterly

Part of the Other International and Area Studies Commons

Breaux, Richard M., "The New Negro Arts and Letters Movement Among Black University Students in the Midwest, 1914-1940" (2004). Great Plains Quarterly. 265.

https://digitalcommons.unl.edu/greatplainsquarterly/265

This Article is brought to you for free and open access by the Great Plains Studies, Center for at DigitalCommons@University of Nebraska - Lincoln. It has been accepted for inclusion in Great Plains Quarterly by an authorized administrator of DigitalCommons@University of Nebraska - Lincoln. 


\title{
THE NEW NEGRO ARTS AND LETTERS MOVEMENT AMONG BLACK UNIVERSITY STUDENTS IN THE MIDWEST, 1914-1940
}

\author{
RICHARD M. BREAUX
}

The 1920s, 1930s, and 1940s were an exciting time for black artists and writers in the United States. Much of the historical literature highlights the so-called Harlem Renaissance or its successor, the Black Chicago Renaissance. Few studies, however, document the influence of these artistic movements outside major urban cities such as New York, Chicago, or Washington, DC. In his 1988 essay on black education, historian Ronald Butchart argued that the educational effects of black social movements such as the Harlem Renaissance on black schooling are unclear

KEY WORDS: African American college students, Aaron Douglas, education, Harlem Renaissance, Midwest, New Negro Movement

Richard M. Breaux is Assistant Professor of Black Studies and History at the University of Nebraska at Omaha. He is currently working on a book manuscript titled, 'These Institutions Belong to the People': New Negro College Students in America's Heartland, 1900-1940.

[GPQ 24 (Summer 2004): 147-62] and underexplored. ${ }^{1}$ This article explores the influence of the New Negro arts and letters movement on black students at four midwestern state universities from 1914 to 1940.

Black students on white midwestern campuses like the University of Kansas (KU), University of Iowa (UI), University of Nebraska (UNL), and University of Minnesota (UMN) aligned themselves with various New Negro philosophies that marked the onset of the New Negro arts and letters movement, or the Harlem Renaissance. The New Negro arts and letters movement had a profound influence on black college students. Black students expressed a New Negro consciousness in at least two ways: (1) they indirectly engaged in the discourses that surrounded the New Negro movement through black scholarly and popular publications, and (2) they engaged in racial vindication through classroom assignments, research, and other intellectual products that challenged prevailing myths of blacks' intellectual and cultural inferiority to whites. Interestingly, black students at KU, UI, UNL, and UMN seemed less interested in who financed the arts movement than in casting their creative works into the growing sea of black 


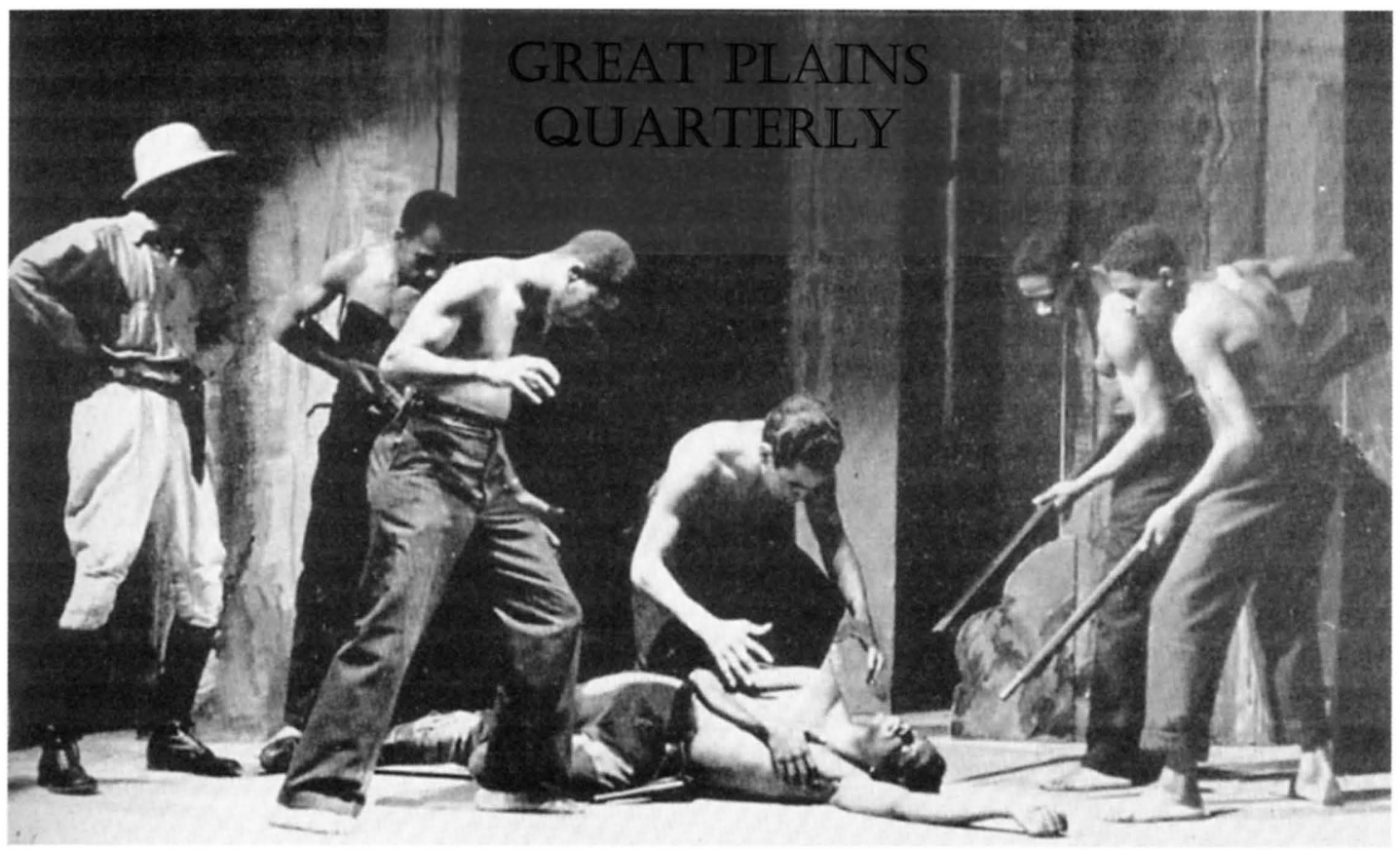

FIG. 1. Black University of Kansas students perform "The Emperor Jones" in October 1939. Reproduced by permission of the publisher from Robert Taft, The Years on Mount Oread: A revision and extension of Across the Years on Mount Oread (Lawrence: University of Kansas Press, 1955), 155.

literature and art. Newspapers such as the Topeka Plaindealer, the Iowa Bystander, and the Omaha Monitor, along with Opportunity and Crisis magazines, artistically and politically inspired black students at KU, UMN, UI, and UNL to behave, dress, and research issues relevant to black people like never before. $\mathrm{Na}$ tional black fraternity and sorority publications such as Alpha Kappa Alpha's Ivy Leaf provided young people the opportunity to publish their creative works. Literary scholars and historians largely ignore such publications, yet these sources offer a different view of the work produced by those associated with various $\mathrm{New}$ Negro arts and letters movements outside Harlem. In fact, black students and alumni did not simply follow the lead of black performing and visual artists in Harlem. These students created their own movement replete with its own poetry, music, and means of expression. Black students from all four univer- sities left their distinct mark on the New Negro arts and letters movement.

As scores of black men returned from World War I, they and many other blacks began to articulate a new militancy. If whites in the United States thought that they would continue to ignore blacks' political, social, cultural, and economic concerns and contributions, they were wrong. An editorial in the Messenger, a black socialist magazine, said it best when it announced, "As among other peoples, the New Crowd [Negro] must be composed of young men who are educated, radical, and fearless. ... The New Crowd would have no armistice with lynch law; no truce with Jim-Crowism, and disfranchisement; no peace until the Negro receives his complete social, economic, and political justice." ${ }^{2}$ This and other New Negro philosophies permeated the minds of black students at UI, UMN, KU, UNL, and other universities. To a small degree, the very pres- 
ence of these black students on predominantly white college and university campuses signaled their endorsement of one of the basic tenets of New Negroism - to demonstrate, consciously or unconsciously, that they were whites' intellectual equals.

When Alain Locke's anthology, The New Negro: An Interpretation, appeared in 1925, those blacks who subscribed to the black intelligentsia's New Negro philosophies finally had their printed manifesto. Of course, in earlier decades Booker T. Washington, William Pickens, and a growing number of Black Nationalist and black socialist magazines had used the term "New Negro," but this term took on new meaning for blacks during and after World War I. "In the last decade," opened Locke's essay in the first section, "something beyond the watch and guard of statistics has happened in the life of the American Negro." 3 Locke asserted that the "Old Negro" and the so-called Negro problem had largely been a charge of the "sociologist, philanthropist, and race leader." Indeed, the Old Negro was a myth, "a creature of moral debate, historical controversy" and a perpetuation of historical fiction. ${ }^{4}$ "The day of 'aunties, 'uncles,' and 'mammies"' was gone, and now many blacks demanded self-respect, self-dependence, self-expression, and self-determination. ${ }^{5}$ The major point stressed by this collection of essays was that black contributions to fiction, poetry, history, philosophy, and the dramatic, performing, and visual arts had existed for centuries. The migration of southern blacks to the urban North just made such contributions more evident.

Despite numerous literary and historical studies on the Harlem Renaissance, scholars continue to disagree about the precise beginning and end of this historical period. The period that spanned from World War I to the Great Depression marks the Harlem Renaissance for Nathan I. Huggins. Historians David Levering Lewis and Bruce Kellner, on the other hand, mark the return of the 369th Infantry Regiment in 1919 as the beginning of the Harlem Renaissance and the year 1934 as the year when the New Negro arts and letters movement came to a "sputtering end." Still others, such as Cheryl Wall, argue for a more generously broad periodization, especially if historians take into account the works of Harlem Renaissance women. ${ }^{6}$ A recent addition to the literature, an examination of the NAACP in the 1920 s, seeks to completely reconceptualize the New Negro movement as the civil rights movement of the Jazz Age, ranging roughly from 1919 to 1930 . While such a classification is a bit of a stretch, it does capture the idea that blacks have continually sought to live on their own social, political, religious, economic, and artistic terms. Harlem may have very well been the "Cultural Capital" for a number of black ethnic groups, but historian Mark R. Schneider reminds us that "to understand African Americans in the 1920s, we must get off the A train to Harlem and head out of Manhattan to points west and south."

For historians who conceptualize the New Negro arts and letters movement by the creative arts and literature produced at the time, or the move of many black intellectuals or working people to the political left, the Chicago arts and letters movement deserves as much attention as Harlem's literary and political explosion. By 1935 Chicago emerged as a black cultural hub in its own right. Although Harlem receives, and has received, the majority of historians' attention, some scholars have also suggested that Chicago became just as important in producing black writers, artists, sociologists, dancers, and Marxists. ${ }^{8}$ While these scholars may agree to disagree about the extent to which the Chicago black arts and letters movement was a continuation of the arts and letters movement in Harlem, at least two points are not debatable: (1) the Chicago arts and letters movement, of which a few UI alumni were a part, lasted at least into the 1940s; and (2) most of Chicago's black artists engaged in dialog with those black artists associated with Harlem.

The history of the New Negro arts and letters movement, like the history of black education in the United States, presses scholars 
to think about white philanthropy and the black arts. While scholars like Nathan I. Huggins and Harold Cruse believed the New Negro movement was a showpiece for white bohemians thirsty for a taste of the nativistic and exotic, others like David Levering Lewis, Ann Douglas, and Thomas Bender see the New Negro arts and letters movement as a constant struggle between two groups of cultural power brokers-white philanthropists and black artists. ${ }^{9}$ In higher education, similar struggles emerged as to what disciplines black students would study, especially in advanced degree programs. Rising accreditation standards in white and black colleges alike precipitated the need for faculty with more specialized, intensive, and advanced training. With the absence of graduate programs on most predominantly black college campuses, and the color line drawn at predominantly white southern colleges, some black college faculty, with assistance from the General Education Board, the Rockefeller Foundation, and the Rosenwald Fund, took courses and graduate degrees at northern white colleges. ${ }^{10}$ Just as northern white philanthropists sought to control the direction of southern black education, a smaller number of white philanthropists developed a similar interest in having some say in the direction of intellectual discourses among an emerging black intelligentsia on northern college campuses.

White philanthropic interest in black intellectual discourse did not begin in the 1920s; this interest went back, at least, to the early Jim Crow era. Indeed, Lois Harlan's two-volume biography of Booker T. Washington demonstrates that in the early twentieth century, a number of white and black power brokers fought for control over black newspapers and political organizations. Blacks who challenged Washington's philosophies found themselves targets of the infamous "Tuskegee Machine." Washington forced some black newspapers that criticized him to shut down, and he arranged for several black critics of Tuskegee to lose their jobs. ${ }^{11}$ White philanthropic interest in black political opinions and scholarship continued after Washington's death in 1915. Historians August Meier and Elliott Rudwick contend that although white philanthropists showed moderate interest in Carter G. Woodson's Journal of Negro History few philanthropists gave generous contributions to studies of black life or black intellectual institutions that were primarily administered or controlled by black scholars and artists before 1922.12

Despite their early philanthropic work among black schools and black teachers, white philanthropists did not establish formal scholarship programs for advanced study among black until the 1920s. The two most powerful and wealthy philanthropic groups that campaigned to develop black teachers, black intellectuals, and leadership were the GEB Fellowship and the Rosenwald Fellowship Fund in 1924 and 1928, respectively. ${ }^{13}$ Both funds gave money for promising black instructors at southern black schools and resources for their instructors to earn credentials and maintain their jobs. They were also inspired by the intellectual and creative direction of the New Negro arts and letters movement, and gave money to a number of creative artists. Between 1922 and 1933 the GEB Fellowship focused almost exclusively on the black teacher shortage, and the Rockefeller Foundation endorsed black students in the medical and health industries. By 1940 GEB Fellowship funds went exclusively to whites and blacks who planned to teach in southern schools. The Rosenwald Fund supported black students in at least four major areas: (1) medicine and nursing; (2) library science and teacher education; (3) unusually promising blacks who would study at northern white or European colleges; and (4) vocational and industrial teachers. ${ }^{14}$ All had to send informal requests to the Rosenwald Fund Committee and those who would teach in southern black schools and college were particularly encouraged. Despite the undeniable influence of the GEB Fellowship and Rosenwald Fund on black education, only a handful of black students at $\mathrm{KU}, \mathrm{UI}, \mathrm{UNL}$, and UMN received funds from 
these organizations. According to the Rosenwald Fund database at Fisk University, a total of eight students who received Rosenwald Fellowships for advanced study between 1928 and 1936 earned master of science, master of arts, or master of music degrees from UMN (3), UI (3), KU (1), or UNL (1). ${ }^{15}$ Some students obviously had changes in their plans because a total of twelve black students chose UMN (9) or UI (3) to complete their advanced study with Rosenwald Fellowship funds. No students requested funds to attend $\mathrm{KU}$ or UNL with Rosenwald money. ${ }^{16}$ Between 1936 and 1941 only two Rosenwald fellows attended UMN, although not one of these students intended to enroll at UMN, UI, UNL, or KU.

Those who received Rosenwald and Rockefeller fellowships were an assorted lot. For example, KU alumnus Sterling V. Owens used a Rosenwald Fellowship to study social work in New York, but ended up taking a job as executive secretary of the St. Paul Urban League. ${ }^{17}$ Owens also lectured at UMN in the 1930s. Similarly, two Georgia State College teachers, Annie Dixon and Clarence Ross, used Rosenwald Fellowship money to study at UMN in the 1930s, but neither earned a degree. Maurice Thomasson used a Rosenwald Fellowship to earn a master's degree in education at UMN so he could become an instructor at Johnson C. Smith College. Ollie Lee Brown turned her money from the Rosenwald Fellowship into a bachelor's degree in library science from UI in 1931. Others, like Elmer E. Collins, received both GEB and Rosenwald Fellowship funds; Collins successfully earned a doctor of medicine degree from UI in 1933 and later taught at Howard University. Vernon A. Wilkerson, who earned a BA at $\mathrm{KU}$, an $\mathrm{MD}$ at UI, and a PhD at UMN, completed his studies with GEB funds, as did one of black America's first women history PhDs, Lulu Merle Johnson, at UI. Johnson later taught at several black colleges including Cheney State University. ${ }^{18}$ Charles W. Buggs, who earned his $\mathrm{MS}$ and $\mathrm{PhD}$ from UMN, found a job at Dillard University and later Wayne State University. ${ }^{19}$ Finally, UNL graduate Aaron

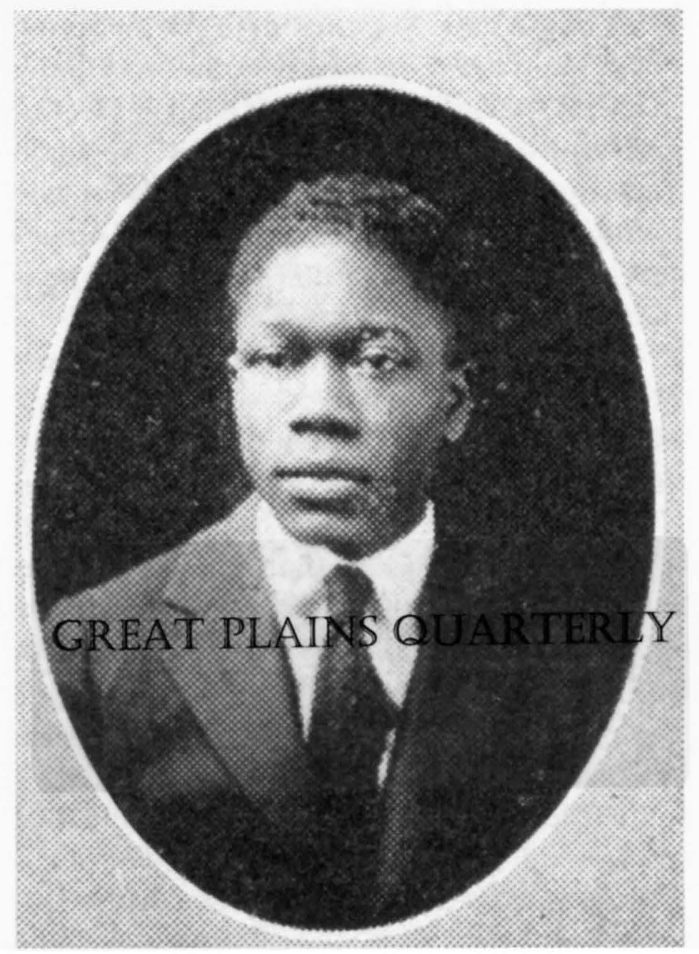

FIG. 2. Aaron Douglas at the University of Nebraska before he became the signature artist of the Harlem Renaissance. Photo from Cornhusker Yearbook (1922), 46. Courtesy of Archives and Special Collections, University of Nebraska-Lincoln Libraries.

Douglas and UI graduate Margaret Walker used Rosenwald Fellowship funds to further their creative works well after they graduated from these institutions. Walker taught at Jackson State University and Douglas taught art at Fisk University. Despite the achievements of these dozen or so recipients, the GEB and the Rosenwald Fellowship Fund's staff had its greatest influence on southern black colleges and blacks who conducted advanced study at the University of Chicago, Columbia University, Hampton Institute, and the larger, more heftily endowed black and white universities. ${ }^{20}$

The Harmon Foundation, like most white philanthropic organizations that gave money to blacks, was not without its critics. While some scholars praise the Harmon Foundation for its role in disseminating black art, others, 
like Mary Ann Calo, criticize it for divorcing black art from its political context, making black art "sociological, rather than aesthetic" and "constricting the critical frame" in which audiences viewed black art. Much of the foundation's writing about black art, argues Calo, "was simply Harmon Foundation publicity posing as art criticism." 21

A New Negro consciousness swept across midwestern college campuses just as it took Harlem by storm. Black students, black alumni, and politically active blacks in Iowa City, the Twin Cities, Lawrence, and Lincoln launched a number of antidiscrimination campaigns in their respective cities. They simultaneously challenged institutional racism in a number of academic disciplines on midwestern college campuses and created an extensive set of intellectual opportunities for themselves.

Outside the classroom, most black students, and a small group of left-thinking white students, embraced the writings of New Negro arts giants such as Countee Cullen, Claude McKay, and Langston Hughes. Members of the Dove, a socialist newspaper at KU, seemed particularly interested in poems such as Countee Cullen's "Yet Do I Marvel" because it symbolized black people's seemingly futile struggle for equality. ${ }^{22}$ Such poems drew upon the tragic Greek stories of both Tantalus and Sisyphus, mythic trickster figures who suffered in Hades for varying reasons and could never quite escape their predicament.

Black students at $\mathrm{KU}$ found the works of Langston Hughes and Claude McKay engaging. Blacks at KU, UI, and UMN not only immersed themselves in Langston Hughes's verses, but in 1932 invited the New Negro movement's poet laureate back home to the Midwest to speak to college students, black and white. At UI, Hughes played to a packed house in the liberal arts auditorium. He read from Weary Blues, his first published book of poetry, and read selections such as "When Sue Wears Red" and "Negro Dancers." He also read his poem "Dressed Up" and reportedly interspersed his poems with reflections of his life experiences. Hughes had graciously accepted the invitation sent under the auspices of the Graduate College to come to UI. Professor Frank L. Mott, a journalism professor who had previously organized a night of black poetry readings, introduced Hughes to the crowd. After Hughes's program he was off to the Alpha Phi Alpha fraternity house where he rested after his lecture. ${ }^{23}$ According to one report, Hughes chatted, joked, and played a few hands of cards with students. ${ }^{24}$ One week after his appearance at UI, Hughes returned to his childhood home in Lawrence. Hughes's mother, Carrie Langston, attended KU in the late nineteenth century, and Langston Hughes lived with his grandmother in Lawrence through the early 1910s. Hughes's lecture in Lawrence was sponsored by Alpha Kappa Alpha Sorority, which delighted in its ability to bring the Midwest kid turned Harlemite to campus in the midst of a depression..$^{25}$ The visit marked the first of three times Hughes returned to Lawrence to speak at $\mathrm{KU}$ after he left the city in $1915 .{ }^{26}$ In 1935 Hughes made a trip to the upper Midwest and spoke to a crowd of 4,000 students at UMN's Northrop Auditorium. According to historian and Hughes biographer Arnold Rampersad, Hughes spoke on the topic of interracial socialism. Hughes argued that "the basic economic problem of the Negro is the same as that of his white compatriots, and it is through the labor movements that some sort of solution must be reached." Hughes made complimentary visits to several classes and a meeting of UMN students. ${ }^{27} \mathrm{He}$ also made a special visit to an offcampus site where at least five students formed a committee to petition UMN officials to defy Tulane University's request to withdraw a black UMN football player from their upcoming match. ${ }^{28}$

During their respective visits to the Twin Cities and UMN, Langston Hughes, Roland Hayes, Paul Robeson, Charles S. Johnson, James Weldon Johnson, and a host of other blacks associated with Locke's New Negro anthology made their way to the UMN and Minneapolis's black Phyllis Wheatley Settlement House in the late 1920s and early 1930s. ${ }^{29}$ 
Often these visitors attended special parties and gave talks or performances for people who used the settlement house's services. The black tenor Roland Hayes played to a packed group on UMN's campus in 1926 and 1929. In his first concert Hayes reportedly "scored his usual triumph" and in his second visit to UMN, students filled the newly completed Northrop Memorial Auditorium to hear Hayes give his performance of European classics and black spirituals. ${ }^{30}$ When Paul Robeson performed in Kansas City, Missouri, in 1927, students traveled from KU to hear the performance. Robeson also performed for white and black students at UMN in 1930. ${ }^{31}$ The following year, black women students at UMN invited Fisk University's Charles S. Johnson to campus to speak on the "Contribution of Negroes to American Civilization." Closer to the end of the decade, and just three years before the infamous Constitution Hall incident, contralto Marian Anderson performed at UMN much to the delight of the Eta chapter of Alpha Kappa Alpha. Anderson also performed at KU's Hoch Auditorium in January 1938. ${ }^{32}$

While the songs of New Negro musicians and the poetry of Harlem's literati became a point of pride among black college students, these students threw their own hats into the literary ring. Some UNL, UI, UMN, and KU students and alumni began to plant the seeds of the New Negro arts and letters movement as early as 1911. William N. Johnson, a former student and football player at UNL, wrote several poems and short stories for the Crisis including a story titled "The Coward," which relayed the tale of Horton, a black plowman who reflects on his family's history as slaves and tenant farmers, and yet refuses to strike back at an abusive landlord:

Back in the dark night of his memory there was only the somber race of plowmen. He seemed to see them, all prototypes of himself, in a single file, plowing the same furrow. The end-the wearying end of the long curving row-was a black chasm. This was his race, the Hortons. They had borne chains with no whining; their great broad backs had been lacerated there at the whipping post by the biting lash, yet they never struck back!

"Damn you, nigger."

It was the landlord's rasping voice that startled the dreaming plowman. A frail bluewhite fist stung his twitching black face. There was pause, and in that pause, the thrush still chanted its anthems to Heaven; Horton the plowman, shrank away from the face of his master. The sweet breeze cooled his hot brow. ${ }^{33}$

Although Johnson's main character did not express characteristics of a New Negro consciousness, Johnson's venture into poetry and short-story writing did.

While a number of historians note that black men often dominate discussions and examinations of a New Negro consciousness expressed through the arts, black women students, particularly at UMN and UNL, turned out a number of poems, songs, short stories, and plays of their own. In the 1920s UMN graduate student Ruth Pearson studied black folklore while she taught in the sociology department. ${ }^{34}$ Zanzye $\mathrm{H}$. Hill received her bachelor's degree from UNL and became the school's first black women law school graduate in 1929. One year before she earned her law degree, Hill wrote a coming of age poem in AKA's Ivy Leaf, titled "My Nantie":

My Nantie she's the funniest thing She looks real hard when I help her sing When company comes, and I run out, To see what they're all laughing 'bout. She just says, you go right back And don't be peeping through the crack Company they say, Oh that's all right She's only just a little might And some day when she grows up tall Then you'll be wishing she small Then company says Nantie, listen dear Why does Mollie act so queer? Nantie looks around to see if I'm listening And if I'm not she began hissing 


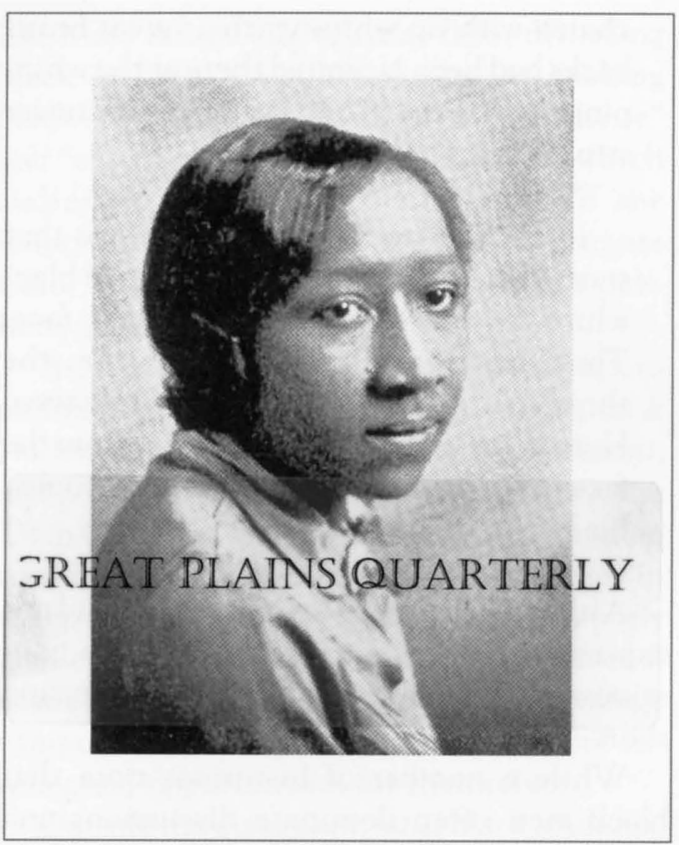

FIG. 3. Zanzye Hill, Poet and first African American woman to receive a law degree from the University of Nebraska. Photo from Cornhusker Yearbook (1929), 49. Courtesy of Archives and Special Collections, University of Nebraska-Lincoln Libraries.

And says, what else could she be The way Mrs. Jones acted at her tea Why I think it was terrible, don't you The way they whispered, just those two And company asks Nantie what was it And Nantie said why it was the rite Her curtains once were white as snow But she decided to make a show And when she went down to the ten-cent store

'Cause she couldn't afford any more And bought herself some dye of red To match she said her bedroom spread I listened hard but couldn't hear any more 'Cause just then my Nantie she shut the door

When I get old and have little girls And company comes to my house I'll never tell them to go and sit And be quiet as a little mouse. ${ }^{35}$
Zanzye Hill also published another poem in the same Ivy Leaf, titled "At Dawning." ${ }^{36}$ Ruth Shores Hill, also a student at UNL, wrote a poem that blended her creative spirit with a solicitation to get more literary contributions to AKA's Ivy Leaf. ${ }^{37}$

Amateur music impresario Florence Webster at KU wrote a poem that many would not classify as representative of the New Negro arts and letters movement; yet a few scholars like Houston Baker and Jon Michael Spencer might argue that Webster evoked one of the era's most misunderstood tropes-the "mastery of form":

A symphony in note was mine With cellos, flutes and violins Tuned in accord to suit the tastes Of critics and without amends The concord must be rarely bent To please the ears of thousands The Melodies are subtle strains For moments soothing hungry souls Appeasing crowds, frustrated mind But unremembered in a time. A symphony in words was yours Played on the strings of hearts-just two Tuned in accord to mark the time Of lovers just for me for you

The harmonies are heaven-sent Oblivious to the thousands The melody is your dear voice Accompanied by tender sighs Crescendos are but raptures taut

To never, never be forgot Oh! Years will pass as must they do

But this has been my happiness Your symphony, I think, is best But God has heard my song for you. ${ }^{38}$

Although these students' poems may not have reflected the more sophisticated style of those poets historians typically associate with the New Negro arts and letters movement, the poems by black women students share some of the themes and styles adopted by New Negro arts and letters movement women writers. Historian Cheryl Wall argues that the cultural 
milieu of the time forced black women to suppress their gender and privilege their race; nevertheless, black women poets were not only less race conscious, but also less innovative in form when compared to black male writers of the time. This meant the black women poets rarely experimented with black vernacular, or cultural expressions such as jazz, blues, or spirituals. ${ }^{39}$ This was certainly the case for black women student writers at KU and UNL. By 1940, however, Margaret Walker, whom Langston Hughes advised to attend a northern college, used literary forms and themes not typically associated with women in the New Negro arts and letters movement to write her poetry. Inspired by Langston Hughes, Robert Hayden, Arna Bontemps, and the emerging young writer Richard Wright, Walker drew on the political environment of the 1930s (the depression, labor struggles, and a literary left) to transform black women's poetry. Two verses from one of the poems that comprised her UI master's thesis spoke to the irony that many blacks felt when they experienced institutional and environmental racism despite their education..$^{40}$ The poems in Walker's master's thesis speak to a folk tradition that only a few black students at UI, UMN, KU, and UNL had an opportunity to study formally.

While a student at UI, Walker recalled that she skipped an entire week of classes to read, and reread, the brand new novel that some scholars argue represented the last rites for the New Negro arts and letters movementRichard Wright's Native Son. Walker recalled that she was in Iowa when she saw a copy of Native Son early in February 1940. Walker remembered that the shock of the book "rocked me on my heels." Walker had developed at least an intellectually passionate friendship with Wright. Before she came to UI, Walker had sent Wright clippings from the Rob Nixon case, which Wright used as a prototype for Bigger Thomas's trial in the novel. ${ }^{41}$

In addition to creative writing and poetry, black students developed an interest in the dramatic arts and play writing. Although most of the plays that students performed were those written by white Negrotarians whose names became attached with Harlem or the New Negro arts and letters movement, a few black students wrote and directed small productions of their own. Eugene O'Neil's The Emperor Jones, Marc Connelly's Green Pastures, and DuBose and Dorothy Heywood's Porgy became favorites among black students on white campuses. In 1929 a member of AKA's Ivy Leaf Club at UNL appeared with other black members of the University Players in a staged production of The Emperor Jones. One year later, an all-black cast of students at KU presented Octavius Roy Cohen's Come Seven. In October 1939 several black students and some white students at KU opened the Speech and Dramatic Arts Department's season double feature with The Emperor Jones. Actor and political activist Paul Robeson had made The Emperor Jones a hit in the screen adaptation of the play. At KU, the reporter for the Daily Kansan appeared much more impressed with black students' acting ability than with the total production: "Last night's reenactment revealed that there is lots of dramatic talent among the negro students of the Campus," wrote the reviewer, "that their peculiar gifts are adaptable to such a theatrical carriage. . . . But, 'My Heart's in the Highlands' was the high spot of the evening's entertainment. It seemed to achieve fully what 'The Emperor Jones' attempted—a strikingly new method of dramatic expression." "42 KU historian Robert Taft immortalized the cast of The Emperor Jones in his book Across the Years on Mount Oread. ${ }^{43}$ Many of these students maintained the Paul Robeson Dramatic Club at KU, which twentythree black students established in $1931 .{ }^{44}$

If local blacks and black and white students in Lincoln and Lawrence applauded the student production of The Emperor Jones, blacks in Lincoln and the Twin Cities launched fullscale campaigns to shut down proposed productions of Porgy at the universities of UNL and UMN. First published as a novel in 1925, and later developed as a play and musical, which attracted scores of whites and some blacks to the theater, Porgy is the story of a 
crippled black beggar who witnesses a murder during a dice game and becomes enamored with the murderer's woman friend. When Crown, the murderer, returns to claim Bess, Porgy kills Bess's ex-lover and escapes conviction because no one can believe a man in Porgy's condition could kill the brutish Crown. Porgy returns to Catfish Row only to discover that Bess becomes strung out on "happy dust" and gets "turned out" into a life as a New York City prostitute.

For some blacks, particularly those outside the arts and among the black middle class, Porgy glorified the worst in black folk and urban street culture. Langston Hughes, a champion of creative license and artistic freedom, praised the theater adaptation of Porgy, but some black actors and celebrities later lambasted the play. In Lincoln, local black ministers organized against the production sponsored by the University Dramatic Club. Ministers claimed, "The play was a deliberate attempt to feature the race at its worst." ${ }^{45}$ If the play continued on as scheduled, they charged, it would intimidate blacks in Lincoln and at UNL, and it would damage the growing spirit of interracial cooperation in the city. Representatives of the drama department refuted the ministers' claims. They maintained that the play was "art with no thought of reflecting on the group," the cast was almost entirely made up of black students, and the suppression of the play would represent an attempt to squash students' artistic expression. ${ }^{46}$

Debates surrounding the production of Porgy became much more heated at UMN. The university's theater department argued in favor of the all-black student production of life in South Carolina's "Catfish Row," but the UMN's Council of Negro Students opposed the production. Caught in the middle, and leaning heavily toward the argument for creative license and free artistic expression, the thirty or so black students hoped the production would proceed. Anne Fenalson, a white associate professor of sociology and advisor to the Council of Negro Students, assured the fifty members who objected to the play that Dr. C. Lowell Lee of the theater department would concede to council demands to replace Porgy with a more suitable production. However, divisions emerged within the council. A second vote of forty-six against the play, six for the play, and twelve who abstained, later gave way to an eighteen-to-sixteen vote to get rid of the play. When theater department officials found no suitable replacement and continued to prepare for the play's opening, the St. Paul and Minneapolis branches of the NAACP and Urban League stepped in to support the Council of Negro Students' slim majority. Spearheaded by the St. Paul NAACP, the group issued a statement that argued that because black students had opposed the production after three votes, "the members of the St. Paul Branch of the NAACP strongly oppose the presentation of this play." 47 This joint committee also threatened to take the matter up before the UMN president Guy S. Ford and the Board of Regents if the theater department ignored its request.

In addition to staging performances of popular plays with their assortment of black characters, black students, particularly black women, at UNL and KU wrote and directed their own mini-dramas. Ruth Shores Hill wrote The Glorious Adventure, a four-scene romantic comedy about black college students who fall in love after discovering their mutual interest in an assigned course reading. ${ }^{48}$ Ruth Gillum at $\mathrm{KU}$ wrote a musical aptly named Heading for Harlem, performed before "an enthusiastic and appreciative audience." ${ }^{49}$ The production and performance of these and other plays demonstrate the degree to which the cultural movement so often associated with Harlem, and on occasion Chicago, spread even farther west.

In the truest spirit of black creativity, white philanthropy, and the New Negro arts and letters movement, several black students won awards and wide recognition for their creative academic work. Clifton Lamb, the director of the Prairie View State College drama department, who studied at UI in the summers to receive a master's degree and maintain his job, 
won a $\$ 100$ first prize and a publishing contract with the Dramatic Publishing Company for his play God's Great Acres. One contest judge remarked that the play, a story of the influence of industrialization on sharecroppers in western Texas, was "a powerful and sympathetic treatment of a phase of the sharecropper problem that has not yet been fully exploited." ${ }^{\circ}$ Beulah Wheeler at UI, Earl Wilkins at UMN, and Charles Stokes at KU won first place in speech contests on their respective campuses in 1921, 1925, and 1927. Wheeler's speech was titled "Uniform Marriage and Divorce Law," Wilkins's topic was "John Doe, Colored Student," and Stokes spoke on "The New Negro." When artist Elizabeth Catlett created the statue Mother and Child for her UI master's project, she walked away with UI's first MFA and a first prize at the American Negro Exhibition in Chicago. Catlett recalled that it was UI professor Grant Wood, not New Negro patriarch Alain Locke, who encouraged her to take on black women as an artistic subject. ${ }^{52}$ Budding writer Margaret Walker, who incidentally was Catlett's UI roommate, earned a master of arts in writing from UI. Her master's thesis, a collection of folk ballads titled For My People, earned her the coveted Yale University Series of Younger Poets award. This published thesis became one of the first books of poetry published by a black woman since New Negro arts poet Georgia Douglas Johnson published her work nearly a decade earlier. Nick Aaron Ford, who came to UI to study for a master of arts in literature while on leave from his teaching post, published his recently completed master's thesis as The Contemporary Negro Novel: A Study in Race Relations. Zatella Turner, who received bachelor's and master's degrees from $\mathrm{KU}$, published My Wonderful Year, a memoir of her time at the University of London, where she studied drama with the assistance of an AKA fellowship. ${ }^{53}$ The New Negro arts movement's signature artist, Aaron Douglas, emerged as an outstanding student while enrolled at UNL from 1917 to 1922 . The "fairhaired boy" of the arts department took his
BFA and won first prize in a student show. ${ }^{54}$ In 1936, fourteen years after Aaron Douglas graduated from UNL with a degree in fine art, the Nebraska Fine Arts Council honored the artist through the acquisition of his painting Window Cleaning, which remains a part of UNL permanent art collection. ${ }^{55}$

Various black intellectuals -who were proponents of the New Negro philosophies significantly influenced visual artists such as Aaron Douglass and Elizabeth Catlett and literary artist Margaret Walker. Douglas and Catlett gained recognition beyond their wildest dreams, and KU and UI also gave birth to other black visual artists influenced by the New Negro arts and letters movement. Tony Hill, K. Roderick O'Neal, and Bernard Goss represent only three examples of those who never became as prominent as Douglas and Catlett and yet received the attention of people like Alain Locke. They helped to develop several more widely known black visual artists. Tony Hill, who graduated with a sociology degree from KU in 1928 and a master's in social work from the University of Chicago, became an internationally known sculptor and ceramics artist. After he honed his skills at the University of Southern California, he enjoyed a celebrated career. ${ }^{56} \mathrm{~K}$. Roderick $\mathrm{O}^{\prime} \mathrm{Neal}$ received his bachelor of arts degree in graphic arts in 1931 and another degree from UI in 1933. As a student, he had exhibitions in the Iowa Memorial Union, and he later developed into one of Illinois's most celebrated architects. ${ }^{57}$ Bernard Goss, who came to UI from Sedalia, Missouri, also exhibited work during his time as a student. Goss's star rose quickly, and Opportunity printed a story about Goss, his work, and other newly arrived black Chicago artists, just five years after his 1935 graduation from UI. While in Chicago, Goss enrolled in the Art Institute, married another aspiring artist, Margaret Taylor, and, with her, developed the South Side Community Arts Center and later founded the DuSable Museum of Black History. Goss's 1939 painting Musicians, appeared in Alain Locke's The Negro in Art..$^{58}$ 
Some historians often admittedly overlook music's influence on the New Negro arts and letters movement. Historian Arnold Rampersad writes in a foreword to a new edition of Alain Locke's influential work, The New Negro: Voices of the Harlem Renaissance, that if he were writing the book again, he would have paid much more attention to the role of music, especially blues and jazz, in the New Negro arts and letters movement. New Negro arts patriarch Alain Locke, Rampersad argues, wholly excluded any mention of the blues, and the editor treated jazz like a wayward stepchild. ${ }^{59}$ Locke and West-Indian-born popular historian Joel A. Rogers certainly believed that black spirituals, as they related to black folk traditions, as well as jazz, symbolized the spirit of New Negroism. ${ }^{60}$ Students and community people usually did not formally engage in jazz, blues, or folk discourses in the classroom, but at dancehalls and house parties one would be hard pressed to hear anything but jazz coming from the phonograph. KU alumnus Nicholas Gerran recalled that although he and other black students did not study jazz formally in the classroom or music departments, this certainly does not mean that black students did not listen to or play jazz outside the classroom. Among many middle-class blacks, "a jazz musician," recalled KU alumnus Nicholas Gerran, "wasn't recognized as an honorable profession." Gerran later joined black KU classmate Florence Webster at the Moscow Conservatory of Music in the Soviet Union. ${ }^{61}$

The connection between classically trained black musicians and the Soviet Union has largely been ignored in Harlem Renaissance and black music history. While several scholars note that Roland Hayes and Paul Robeson performed in Moscow, and Alain Locke praised the Soviet Union for its policy toward ethnic minority artistic development, few have explored the depth to which Russian and black folk music, or Soviet classical and black classical music traditions, influenced each other. All these artists, including the young student Nicholas Gerran, took note of the lack of prejudice they experienced in the Soviet Union, but the question that remains, although outside the scope of this study, is how did these experiences influence black musicians' view of Communism? Did the Stalinist-Hitler pact alter their view of Communism? Outside of Paul Robeson, we know very little about how the Soviet Union, Communism, or the Moscow Conservatory shaped black musicians' political philosophies. ${ }^{62}$

The sheer number of black students, particularly black women, who seemed to have some classical music training may seem phenomenal now, but such was a typical genderappropriate undertaking during the first decades of the twentieth century. As early as 1908 , several black women and men who were enrolled in KU's music department performed vocal, violin, and piano solos at musicals held at St. Luke AME church. KU students like Doris R. Novel, Etta G. Moten, Ruth Gillum, Maxine Bruce, and Lillian Webster continued this tradition well into the $1930 \mathrm{~s}^{63}$ Cleopatra Ross, a fine arts student at UNL, played the piano, the pipe organ, and sang at a number of recitals and black student programs held at Quinn Chapel AME and First Christian churches. ${ }^{64}$ Three years later, members of APHIA at UNL, with help from AKA, sponsored a similar recital at Quinn Chapel. ${ }^{65} \mathrm{KU}$ graduate Etta G. Moten took her guitar, piano, and singing talents to the national concert stage, screen, radio, and equally shared it with chapters of AKA throughout the country. ${ }^{66}$

For many scholars today, classically trained black musicians who perfected European musical traditions do not merit a place among those who embraced any form of New Negroism. Black intellectuals young and old debated the issue of what types of plays, poetry, literature, and music should represent black people. Literati writers Claude McKay and Langston Hughes appreciated black performances of more mainstream and classical troupes affiliated with the white middle class as long as they rightfully shared a place with black spirituals, jazz, and blues. Still, few historians of the New Negro arts and letters movement share McKay's and Hughes's opinion. 
Music historians Jon Michael Spencer and Paul Allen Anderson argue that black classical musicians and jazz and blues musicians engaged in what literary scholar Houston Baker calls the "mastery of form" and the "deformation of mastery." ${ }^{67}$ Baker, and Spencer building on Baker's thesis, suggests that both the "mastery of form" and the "deformation of mastery" were attempts to usurp racism. The "mastery of form" required that blacks, particularly black students, perfect Anglo-Saxon, upper-class white American and European "high culture" in an effort to force white people to see black people's humanity and respect blacks as equals. Within the area of education, "mastery of form" translated into mastering the "form of 'standard' educational process in the West." ${ }^{68}$ Yet some blacks, even college students, engaged in a "deformation of mastery," a conscious effort to deconstruct mainstream culture, literature, and music through a black rural folk and black urban cultural lens. To be sure, Baker maintains that deformation is "a go(uer)rilla action in the face of acknowledged adversaries." Moreover, deformation "distinguishes rather than conceals. It secures territorial advantage and heightens a group's survival possibilities." ${ }^{\circ 9}$ On rare occasions, students like George $\mathrm{O}$. Caldwell managed to incorporate black folk music into his thesis at UI when he compared traditional black folk songs to Russian composer Igor Stravinsky's 1910 ballet Firebird. ${ }^{70}$

A small number of sources offer a view of black student life that demonstrates that all students were not trying to put up a middleclass front. In their leisure time, students demonstrated an affinity for the blues and blues musicians, who were constantly in the act of deforming mainstream culture. To be sure, black students at UNL, who were by many accounts more working class than their contemporaries at $\mathrm{KU}, \mathrm{UI}$, and UMN, listened to and performed songs like the "St. James Infirmary Blues," "Just a Gigolo," "Baby Won't You Please Come Home," and "He May Be Your Man But He Comes to See Me Sometimes."

The spirit and sociopolitical consciousness that surrounded the New Negro arts and let- ters movement in Harlem and the black arts and letters movement in Chicago emerged as an enormous influence in the intellectual lives of black KU, UMN, UNL, and UI students and alumni. The examples of students' creative work, however, demonstrate that students also produced their own poetry, fiction, and visual arts, and by extension their own arts movement. Despite historical debates about who should and should not be termed New Negroes, sources from the 1910s, 1920s, and 1930 s reveal that blacks with a variety of talents and political views deserved the title New Negroes.

\section{NOTES}

1. Ronald Butchart, "Outthinking and Outflanking the Owners of the World: A Historiography of the African American Struggle for Education," History of Education Quarterly 28, no. 3 (Autumn 1988): 361. The standard work about the New Negro movement at historically black colleges and universities remains Raymond Wolters, The New Negro on Campus: Black College Rebellions of the 1920s (Princeton, NJ: Princeton University Press, 1975).

2. A. Philip Randolph, "A New Crowd-A New Negro," Messenger, May-June 1919, 27.

3. Alain Locke, "The New Negro," in The New Negro: An Interpretation, ed. Alain Locke (New York: Albert and Charles Boni, Inc. 1925), 3.

4. Ibid., 3.

5. Cheryl Wall, Women of the Harlem Renaissance (Bloomington: Indiana University Press, 1995), 2; Alain Locke, foreword to New Negro, ix; Locke "New Negro," 4, 5.

6. Nathan I. Huggins, Harlem Renaissance (New York: Oxford University Press, 1971), 3012; David Levering Lewis, When Harlem Was in Vogue (1997; New York: Penguin Books, 1981), xxviii; Wall, Women of the Harlem Renaissance, 10.

7. Mark Robert Schneider, "We Return Fighting": The Civil Rights Movement in the Jazz Age (Boston: Northeastern University Press, 2002), 4.

8. James Edward Smethurst, The New Red Negro: The Literary Left and African American Poetry, 1930-1946 (New York: Oxford University Press, 1999), 5; Robert Bone, "Richard Wright and the Chicago Renaissance," Callaloo 28 (Summer 1986): 446-68; Joyce Russell-Robinson, "Renaissance Manqué: Black WPA Artists in Chicago," Western Journal of Black Studies 18, no. 1 (1994): 36-43; Craig Werner, "Leon Forrest, the AACM and the 
Legacy of the Chicago Renaissance," Black Scholar 23, nos. 3-4 (1993): 10-23.

9. Lewis, When Harlem Was in Vogue, xxiii; Ann Douglas, Terrible Honesty: Mongrel Manhattan in the 1920s (New York: Noonday, 1996); Thomas Bender, New York Intellect: History of Intellectual Life in New York from 1750 to the Beginning of Our Time (New York: Knopf, 1987).

10. Jayne R. Beilke, "To Render Better Service: The Role of the Julius Rosenwald Fund Fellowship Program for the Development of Graduate and Professional Educational Opportunities for African Americans" (PhD diss., Indiana University, 1994); Horace Mann Bond, The Education of the Negro in the American Social Order (1934; New York: Octagon Books, 1966), 364; James D. Anderson, The Education of Blacks in the South, 1860-1935 (Chapel Hill: University of North Carolina Press, 1988), 275-77.

11. For more on the power and influence of the "Tuskegee Machine," see Louis Harlan, Booker T. Washington: The Making of a Black Leader, 1856 1901 (New York: Oxford University Press, 1972), 254-71; Louis Harlan, Booker T. Washington: The Wizard of Tuskegee, 1901-1915 (New York: Oxford University Press, 1983), 84-106.

12. August Meier and Elliott Rudwick, Black History and the Historical Profession, 1915-1980 (Urbana: University of Illinois Press, 1986). For more on the roller-coaster ride to finance the JNH in the early years, and the role of Rosenwald, Carnegie, and the Laura Spelman Rockefeller Memorial Fund, see Darlene Clark Hine, "Carter G. Woodson: White Philanthropy and Negro Historiography," in Hine Sight: Black Women and the ReConstruction of American History, by Darlene Clark Hine (Brooklyn, NY: Carlson Publishing, 1994), 203-22.

13. Beilke, "To Render Better Service," 50.

14. Ibid., 51-52, 61-63.

15. Ibid., 157-59.

16. Ibid., 159-60.

17. Earl Spangler, The Negro in Minnesota (Minneapolis: T.S. Denison and Co., 1961), 126.

18. Harry Washington Greene, Holders of Doctorates among American Negroes (Boston: Meador Publishing, 1946), 63, 136.

19. Beilke, "To Render Better Service," 68.

20. A much smaller, yet equally important white philanthropic fund to the New Negro arts and letter movement's proliferation was the William E. Harmon Foundation. The white Negrotarian and New York real estate magnate William E. Harmon acquired the resources, after several successful business ventures, to leave Iowa for New York. From his post in New York, William E. Harmon developed the Harmon Foundation, which, among other things, sponsored traveling exhibits of black art and bestowed the Distinguished Award for Achievement Among Negroes prize. Archie Alexander, black UI alumnus and architect, received the Harmon Prize in 1927. "Archie Alexander Given the Harmon Award," Omaha Monitor, March 11, 1927.

21. Mary Ann Calo, "African American Art and the Critical Discourse between World Wars," American Quarterly 51, no. 3 (1999): 587. For opposing views of the Harmon Foundation's work, see Calo, "African American Art," and William S. Doan, "Iowa and the Artist of African Descent," in Outside In: African Americans in Iowa, 1838-2000, ed. Bill Silag, Susan Koch-Bridgford, and Hal Chase (Des Moines: State Historical Society of Iowa, 2001), 497-99.

22. Countee Cullen, "Yet Do I Marvel," reprinted in the Dove, February 15, 1926.

23. "Mott Talks to Group on 'Negro Poetry," Daily Iowan, February 27, 1932; "Negro Poet to Give Lecture," Daily Iowan, March 1, 1932; Margaret Schlundt, "Hughes Paints Vivid Portrait of Negro Life," Daily lowan, March 4, 1932.

24. "Alpha Phi Alpha," Daily Iowan, March 5. 1932.

25. "Delta Doin's," Ivy Leaf, March 1932, 6.

26. Alison Watkins, "Celebrating Langston Hughes," in Lawrence: The Art of a City (Lawrence: Convention and Visitor's Bureau, 2001-2), 46-47.

27. Arnold Rampersad, The Life of Langston Hughes: I, Too, Sing America, vol. 1, 1902-1941 (New York: Oxford University Press, 1986), 313. Rampersad also mentions the campus visits to UI and $\mathrm{KU}$ in 1932; see Rampersad, Life of Langston Hughes, 1:234.

28. "Tulane's Attitude on Reed Sought," Minnesota Daily, October 15, 1935.

29. Michiko Hase, "W. Gertrude Brown's Struggle for Racial Justice: Female Leadership and Community in Black Minneapolis, 1920-1940" (PhD diss., University of Minnesota, 1994), 31.

30. "The Concert Courses," Gopher (1927), 205; "The University Concert Courses," Gopher (1930), 208.

31. "Paul Robeson," Topeka Plaindealer, January 14, 1927; "The University Artists Course," Gopher (1931), 174, 176; "Record Audience to Pack Northrop to Hear Robeson," Minnesota Daily, February 11,1931 . Both Hayes and Robeson are noted in Alain Locke, "The Negro Spirituals," in New Negro, 208.

32. "Negro Sociologist to Be Guest at Tea," Daily Minnesotan, January 30, 1931; "Visiting Artists," Gopher (1936), 218; "University Concert Course," University Daily Kansan, January 13, 1939. In 1939 the Daughters of the American Revolution pro- 
hibited Anderson from performing at Constitution Hall. First Lady Eleanor Roosevelt responded by resigning from the Daughters of the American Revolution and arranged for Anderson to sing at the Lincoln Memorial.

33. Will N. Johnson, "The Coward," Crisis, October 1911, 252. Also see "The Call," Crisis, November $1916,15$.

34. "Who's Who"Opportunity, November 1925, 341.

35. "Deaths," The Nebraska Alumnus, May 1935,

28; J. Clay Smith, Emancipation: The Making of the Black Lawyer, 1844-1944 (Philadelphia: University of Pennsylvania Press, 1993), 328, 465, 471.

36. Zanzye H. Hill, "My Nantie," Ivy Leaf, November 1928, 46; Zanzye H. Hill, "At Dawning," Ivy Leaf, November 1929, 16.

37. Ruth Shores Hill, "A Reporter's Query," Ivy Leaf, June 1931, 31.

38. Florence M. Webster, "Symphony," Ivy Leaf, June 1931, 30. Also see poem by UNL student Ellen Roy, "To Alpha Kappa Alpha," Ivy Leaf, June $1931,29$.

39. Wall, Women of the Harlem Renaissance, 6 , $12-13$.

40. Margaret Walker, For My People (New Haven: Yale University Press, 1942), 13.

41. Margaret Walker, Richard Wright, Demonic Genius: A Portrait of the Man, A Critical Look at His Work (New York: Amistad Press, 1988), 146, 122-25.

42. "Alpha Theta," Ivy Leaf, March 1929; "Delta Doin's," Ivy Leaf, September 1930, 5; Ken Postlethwaite, "Double Feature Opens Dramatic Season," University Daily Kansan, October 31, 1939.

43. Robert Taft, Across the Years on Mount Oread (Lawrence: University of Kansas Press, 1955), 155.

44. "Robeson Club to Give Play," University Daily Kansan, March 17, 1932; Jayhawk (1936), 364, 369; Jayhawk (1937), 375, 381.

45. J. Harvey Kerns, "Social and Economic Status of the Negro in Lincoln, Nebraska" (Race Relations Committee in Lincoln, 1933), 28, Nebraska Historical Society, Lincoln, NE.

46. Ibid., 28.

47. "N.A.A.C.P. Branches To Seek Ban on 'U' Production of Disputed Play 'Porgy," St. Paul Recorder, November 17, 1939. Article includes the resolution printed in its entirety.

48. Ruth Shores Hill, "The Glorious Adventure," Ivy Leaf, June 1931, 35.

49. "Delta," Ivy Leaf, March 1934, 21.

50. "Drama of Negro Life Ties for First Prize in Iowa Contest," Opportunity, September 1939, 279.

51. "Beulah Wheeler Wins Contest By Default," Daily Iowan, January 12, 1921; "Women to Speak Tonight at 7:30," Daily Iowan, January 18, 1921; "Non-Literary Woman Given First Place in Extempore," Daily Iowan, January 20, 1921; "Women's
Extempore Contest," Hawkeye (1922), 325; "Freshman-Sophomore Oratorical Contest," Gopher (1927), 236; "Kansas Student Wins Cup With 'New Negro' Oration,” Omaha Monitor, December 30, 1927.

52. Elizabeth Catlett, letter to the author, January 16, 1999; Samella Lewis, The Art of Elizabeth Catlett (Claremont, CA: Hancraft Studios, 1984), 23; Michael Brenson and Lowery Stokes Sims, Elizabeth Catlett Sculpture: A Fifty-Year Retrospective Purchase, NY: Neuberger Museum of Art, SUNY, 1998), 12-13; Melanie Herzog, Elizabeth Catlett: An Artist in Mexico (Seattle: University of Washington Press, 2000), 17-23.

53. "Former Negro Graduate's Book to Be Published," University Daily Kansan, November 2, 1939.

54. Amy Helene Kirschke, Aaron Douglas: Art, Race, and the Harlem Renaissance (Jackson: University Press of Mississippi, 1995), 6-7. Douglas also enrolled at UMN for a short time after he was removed from the Student Army Training Corps. For a study of the philosophical foundations of Douglas's work, see Audrey Thompson, "Great Plains Pragmatist: Aaron Douglas and the Art of Social Protest," Great Plains Quarterly 20, no. 4 (Fall 2000): 311-22.

55. Margaret Walker, For My People; "Painting," clipping, and "1922," clipping, "Douglas, Graduate of School of Fine Arts, Lauded for Drawings," MS\#159, folder 1, Box MS \#158-161, Aaron Douglas File, University of Nebraska at Lincoln Archives, Lincoln, NE.

56. "Ceramics by Tony Hill," Ebony, November 1946, 31-34; "Tony Hill," in A Biographical History of African American Artists, A-Z, Anderson Delano Macklin, (Lewiston, NY: Edwin Mellen Press, 2001), 128.

57. Theresa Dickason Cederholm, "Kenneth Roderick O'Neal," Afro-American Artists: A BioBibliographical Directory (Boston: Trustees of the Boston Public Library, 1973), 58; "Roderick O'Neil-Leader among Negro Architects," Iowa Alumni Review, October 1954, 10-11.

58. Willard F. Motley, "Negro Art in Chicago," Opportunity, January 1940, 20-21; Macklin, "Bernard Goss," in Biographical History of African American Artists, 107; Alain Locke, The Negro in Art (Washington, DC: Association in Negro Folk Education, 1940), 117, 132; see Goss illustrations in a book of unpublished poems celebrating his life, Evangeline Zehmer, "Form of a Woman" (unpublished booklet, 1976), Margaret Taylor Goss Burroughs Papers, Chicago, IL. Copy in author's possession.

59. Arnold Rampersad, introduction to The New Negro: Voices of the Harlem Renaissance, by Alain Locke (1925; New York: Atheneum, 1992), xx. 
60. Alain Locke, "The Negro Spirituals," in New Negro: An Interpretation, 199-213; J. A. Rogers, "Jazz at Home," in New Negro: An Interpretation, 216-24.

61. Nichols Gerran interview, reprinted in Narratives of African Americans in Kansas, 1870-1992 (Lewistown, NY: Edwin Mellen Press, 1993), 68, 69-70; "Florence Webster," Ivy Leaf, September 1936, 13. For more on blacks and their interest and trips to Russia during this period, see John L. Garder, "African Americans in the Soviet Union in the 1920s and 1930s: The Development of Transcontinental Protest," Western Journal of Black Studies 23, no. 3 (1999): 190-200.

62. Paul Allen Anderson, Deep River: Music and Memory in Harlem Renaissance Thought (Durham, NC: Duke University Press, 2001), 160-62.

63. "Lawrence, Kansas," Topeka Plaindealer, March 6, 1908; "Soror Doris Reita Novel," Ivy Leaf, November 1928, 72; "Delta Doin's," Ivy Leaf, December 1930, 9; "Delta," Ivy Leaf, June 1929; "Delta Doin's," Ivy Leaf, September 1930, 5; "More Graduating Sorors," Ivy Leaf, September 1936, 17; Walter Belk, "The Lawrence Black Community and Its Relationship to Black Students on Mount Oread, 1870-1930," Sociology 165 paper, University of Kansas, Unpublished paper, Watkins Community Museum, Lawrence, Kansas, May 10, 1971, 17-18. 64. "Lincoln, Neb.," Omaha Monitor, April 13, 1928; "Lincoln, Nebraska," Omaha Monitor, May 25, 1928; "Soror Cleopatra Elaine Ross," Ivy Leaf, November 1928, 65.
65. "Negro Musicians Will Give Recital Tonight," Daily Nebraskan, January 16, 1931.

66. "Soror Moten," Ivy Leaf, March 1935, 3. Moten met with AKA members at UMN before a concert in a Minneapolis theater.

67. Claude McKay, The Negroes in America, trans. Robert J. Winter (1921; Port Washington, NY: Kennikat Press, 1979), 60-61; Langston Hughes, "The Negro Artist and the Racial Mountain," Nation 122 (June 28, 1926): 692-94; Jon Michael Spencer, The New Negroes and Their Music: The Success of the Harlem Renaissance (Knoxville: University of Tennessee Press, 1997), xxii; Anderson, Deep River, 7, 9, 10.

68. Houston Baker, Modernism and the Harlem Renaissance (Chicago: University of Chicago Press, 1987), xv.

69. Ibid., 50, 51 .

70. George O. Caldwell, "A Comparison of Selected Material of Stravinsky's Firebird with Traditional Negro Folk Music," (master's thesis, University of lowa, 1932).

71. Ruth Shores Hill, "Alpha Theta Chapter," Ivy Leaf, June 1931, 37-38. David Levering Lewis notes that black women dressed as men performed "St. James Infirmary Blues"; see Lewis, When Harlem Was in Vogue, 242. Louis Armstrong recorded the "St. James Infirmary Blues" in 1929 and Cab Calloway recorded the same tune in 1930. Blues singer Bessie Smith recorded "Baby Won't You Please Come Home" in 1923. 